\title{
Mental Health
}

\section{The Bournewood Fright}

\section{by Graham Ritchie}

The recent House of Lords case of $R$ v Bournewood Mental Health Trust, ex parte L [1998] 3 WLR 107-128 has, to a large extent, settled grave concerns amongst those responsible for the care and treatment of mentally disordered people, including mental health trusts, mental health charities, the Mental Health Act Commission, the Royal Society of Psychiatrists, the Department of Health, and proprietors of residential and nursing care homes, which arose after the Court of Appeal decision in the same matter ([1998] 2 WLR 764).

This case illustrates the finer aspects of the intermeshing of statute law with common law and also how easy it is to spend time 'reinventing the wheel' when the issues being strained at have already been thought out by earlier generations. Another example of this is the constant and revolving argument about the welfare principle in the law applying to children.

The principle can be shortly stated: that the welfare of children is of paramount importance. It is the first consideration in any decision concerning children. In practice, this tends to mean that the court tries to achieve the best interests of the child in the circumstances. This has been so stated constantly from the last century. Successive generations of practitioners seek constantly to restate it as some form of new insight but, as with many basic principles of our civilisation, the principle is more or less immutable until such time as the basis of our civilisation changes.

The question of if, when, and whether a person who lacks mental capacity can give, or does give, consent to nursing care and treatment is not one of these great immutable principles, but it had been thoroughly thought out during the 1950s before the Court of Appeal grappled with the issue. This seems to have escaped notice until it was explained to the House of Lords in June 1998.

\section{BOURNEWOOD: THE FACTS}

The 48-year old applicant is autistic with learning disabilities. He is liable to self-injury and agitation. He is incapable of indicating consent to medical treatment.

He was in residential care with Bournewood Community and Mental Health NHS Trust and its predecessor authorities for 37 years, before being placed with carers in the community in 1994 (presumably pursuant to the NHS and Community Care Act 1993), as he remained the responsibility of the Trust.

In 1997 there was an episode of agitation and self-harm at his day centre His carers could not be contacted and the responsible social worker arranged for him to go to the local casualty department. It was decided there that he should be re-admitted to the behavioural unit of his old long-stay hospital for his condition to be stabilised. He was admitted to an unlocked ward as an informal patient because he was not showing any wish to leave hospital. If he had wanted to leave hospital and was being non-compliant with nursing care he would have been compulsorily detained under s. 3 of the Mental Health Act 1983. His carers in the community took the view that he was being unlawfully detained and an application was made in the High Court on his behalf for judicial review, an order of habeas corpus ad subjudiciendum and damages for false imprisonment and assault.

The judge, at first instance, held that, whilst the Mental Health Act 1983 covered all aspects of formally detained mental patients, s. 131(1) of the Act preserved the common law jurisdiction in respect of informal patients. Since the applicant had been informally admitted, and the elements of the common law principle of necessity had been established, the applicant had not been unlawfully detained.

The applicant appealed to the Court of Appeal which found that s. 131(1) of the Mental Health Act 1983 was only concerned with those patients who could indicate consent to informal admission and so, as this applicant was too disabled to articulate consent, his admission amounted to an unlawful detention. The
Trust therefore detained the patient under s. 3 of the Mental Health Act 1983 before ultimately discharging him back to his carers in the community.

This decision at once raised concern around the country amongst those responsible for the care of compliant patients who lacked mental capacity, as it meant that unless they were all formally admitted to their caring institutions under s. 2-5 of the Mental Health Act 1983 those institutions would be acting unlawfully. The implications of this for resource allocation are outlined below.

The Trust appealed from the Court of Appeal decision to the House of Lords, which decided that the appeal should be allowed:

\section{... Parliament, in enacting the Mental} Health Act 1983, had recognised that persons suffering from mental disorder who were treated for their condition as in-patients in hospital fell into two categories, those who were compulsorily and formally admitted regardless of their will under sections 2 to 5 of the Act, and those who were informally admitted under section 131(1) of the Act; that section 131(1) was in identical terms to, and was to be construed in the same way as, section 5(1) of the Mental Health Act 1959 , which had allowed the informal admission of both consenting patients and those who, without the capacity to consent, had not manifested any objection, and the basis upon which a hospital was entitled to care for and treat such compliant incapacitated patients was the common law doctrine of necessity; that although the taking of the applicant to hospital could be said to have been a detention in the sense that, in the absence of justification, the tort of false imprisonment would have been committed, the decision that he should remain in hospital after readmission under section 131(1) did not (Lord Nolan and Lord Steyn dissenting) amount to an actual detention, since he had been placed in an unlocked ward and the possibility of lawful restraint had he sought to leave had not given rise to his detention in fact at any earlier date; that since all steps taken had been done in accordance with the trust's duty of care to the applicant and in his best interests, to the 
extent that the applicant had been detained such detention had been justified by the common law doctrine of necessity; and that, accordingly, the tort of false imprisonment had 'not been committed against the applicant' ([1998] 3 WLR 108).

The Court of Appeal had taken a different approach to the definition of detention. It held that $\mathrm{L}$ had been detained:

'In our judgment a person is detained in law if those who have control over the premises in which he is have the intention that he shall not be permitted to leave those premises and have the ability to prevent him from leaving. We have concluded that this was and is the position of L.' ([1998] 2 WLR 764, at p. 769)

The Court of Appeal concluded that the Mental Health Act 1983 effected a 'complete regime' which excluded the common law doctrine of necessity.

\section{CONSEQUENCES OF THE JUDGMENT}

Thousands of people receiving treatment would now have to be detained under s. 2-5, Mental Health Act 1983. While the average number of detained patients resident on any one day in England and Wales is approximately 13,000, the Mental Health Act Commission estimated:

'there will be an additional 22,000 detained patients resident on any one day as a consequence of the Court of Appeal judgment plus an additional 48,000 admissions per year under the Act.' ([1998] 3 WLR 112)

In the view of the Mental Heaith Act Commission, the majority of the patients to whom the Court of Appeal decision applied were long-stay patients and it considered that if the Court of Appeal judgment held then the judgment would also apply to patients receiving medical treatment for mental disorder in mental nursing homes not registered to receive detained patients, and the above estimates were likely to be very much higher.

There were resource implications for the mental health services, and professionals, responsible for implementing the Mental Health Act 1983, but also for the administration of Mental Health Tribunals, and the Mental Health Act Commission. Apart from resource implications, the impact on patients, their relatives and carers had to be considered.

The President of the Royal Society of Psychiatrists, the Chairman of the Faculty for Psychiatry and Old Age of the Royal Society of Psychiatrists, the Executive Director of the Alzheimer's Disease Society all expressed concern about the effect of the judgment.

The Mental Health Act Commission raised the question of whether mental nursing homes now had to be registered to receive patients detained under the Mental Health Act 1983 before receiving residents like $\mathrm{L}$. The question arose as to whether unregistered homes had to discharge patients like $L$ from their care.

The question also arose as to the legal status of the many thousands of elderly people in nursing or residential homes, receiving respite care and temporary care, who lack the capacity to consent to treatment.

\section{SECTION 131(1), MENTAL HEALTH ACT 1983}

Patients receiving treatment in a mental hospital fall into two legal categories:

(1) Those patients who are admitted to hospital under s. 2-5, Mental Health Act 1983. They have been compulsorily and formally admitted to hospital for assessment/treatment which can only be provided in hospital and it is necessary for the health or safety of the patient or for the protection of others. This is usually against the wishes of the patients to varying degrees at the time.

(2) Those patients who enter hospital as in-patients for treatment by consent and those patients who do not have the capacity to consent, or indicate consent, but do not express, by any means, any objections to admission. These patients are admitted under s. 131(1) Mental Health Act 1983 without the formalities (and therefore legal protection) of s. 2-5.

This section is drafted in identical terms to s. 5(1) of the Mental Health Act 1959. The 1959 Act was drafted in the light of the Report of the Royal Commission on the Law Relating to Mental Illness and Mental Deficiency 1954-1957 (1957) (Cmnd 169) 9, 'the
Percy Commission'). Pages 100-101, at para. 289, 290 and 291, of the report are quoted in the House of Lords judgment at p. 114

'We consider compulsion and detention quite unnecessary for a large number, probably the great majority, of the patients at present cared for in mental deficiency hospitals, most of whom are childlike and prepared to accept whatever arrangements are made for them. There is no need to have power to detain these patients in hospital rather than in their own homes or any other place which they have no wish to leave. We strongly recommend that the principle of treatment without certification should be extended to them. Such a step should help to alter the whole atmosphere of this branch of the mental health services. Many parents of such severely sub-normal children at present feel that they lose all their rights as parents when the child is admitted to hospital and automatically becomes subject to compulsory detention there. We have no doubt that the element of coercion also increases the resentment of some feebleminded psychopaths, and of their parents, when they are placed under 'statutory supervision' or admitted to mental deficiency hospitals after leaving school, and that this makes it even more difficult than it need be to persuade them to regard these services in the same way as other social services and other types of hospital treatment, as services which are provided for their own benefit. Equally important, if the procedures which authorise detention become the exception rather than the rule, the attitude towards compulsion on the part of those administering the service should change. These procedures will no longer be a formality which must be gone through before any patient can be given the care he needs. It will be possible to consider the need for care and the justification for compulsion as two quite separate questions in a way which is not possible at present.

\section{Admission to hospital without using} compulsory powers should also be possible for considerably more mentally ill patients than are at present admitted as voluntary patients.

We therefore recommend that the law and its administration should be altered, in relation to all forms of mental disorder, by abandoning the assumption that compulsory powers must be used unless the patient can express a positive desire for treatment, and replacing this by offer of care, without deprivation of liberty, to all who need it and are not unwilling to receive it. All hospitals providing psychiatric treatment should be free 
to admit patients for any length of time without any legal formality and without power to detain.'

After quoting the above, Lord Goff then goes on to state (at p. 115 of his judgment):

'Here we find a central recommendation of the Percy commission, and the mischicf it was designed to cure. This recommendation was implemented, in particular, by section 5(1) of the Act of 1959. That the Bill was introduced with that recommendation is confirmed by ministerial statements made in Parliament at the time: see Hansard (HL Debates, 4 June 1959, cols. 668 and 669)

Following the enactment of the Act of 1959, section 5 (1) was duly implemented in the manner foreshadowed by the Percy commission, a practice which (as is plain from the evidence before the committee) has been continued under section 131(1) of the Act of
1983, which is in identical terms. It is little wonder therefore that the judgment of the Court of Appeal in the present case, which restricts section 131 (1) to voluntary patients, should have caused the grave concern which has been expressed in the evidence, both (1) about the need, following the Court of Appeal's judgment, to invoke the power of compulsory detention in many cases, numbered in their thousands each year, which for nearly 40 years had not been necessary and would, on the view expressed by the Percy commission, be wholly inappropriate, and (2) about doubts whether some categories of patients would or would not, in consequence of the judgment, require compulsory detention.'

At p. 116 of his judgment Lord Goff states:

'I am unable with all respect to accept the opinion of the Court of Appeal on the crucial question of the meaning of section 131(1). I wish to stress, however, that the statutory history of the subsection, which puts the matter beyond all doubt, appears not to have been drawn to the attention of the Court of Appeal ...'

It seems that not only had this issue been fully thought through in the early 1950s, but a seamless harmony between common law and statute law was taken for granted. Perhaps somebody should be trawling through the minutes of the 19 th century Lunacy Commissioners to rediscover what robust common sense and wisdom might be overlooked in present practice!

Graham Ritchie

Ritchie Samuel, Cambridge

\section{European Law}

\section{Liberalisation of postal services in the EU by Cameron McKenna, Brussels}

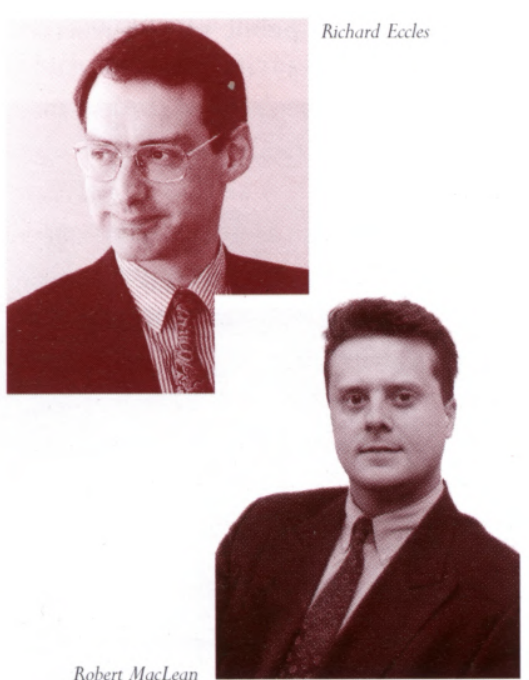

The postal services sector is now emerging at the forefront of the evolution of EC competition law. European Commission proposals were due at the end of 1998 and, at the time of writing are expected imminently, for further liberalisation of the sector. This follows the cxisting internal market directive on postal services, Directive $97 / 67$ on common rules for the development of the internal market of Community postal services and the improvement of quality of service (OJ 1998 L15/14). These proposals can be expected to set out a challenging time-scale for full liberalisation of the sector. The new measures will in any event result in incumbent monopoly operators facing competition in areas currently reserved to them. Directive $97 / 67$ and the Commission's competition law decisions in the sector have all reflected a strong concern to maintain a strict link between the quality of service provided and the proportionality of any restrictions of competition. The Commission is understood to have undertaken a series of studies as the basis for the further liberalisation proposals now due, with regard, inter alia, to cross-border mail, the weight and price thresholds and the clearance, sorting and transport of mail.

Europe's postal services sector is already becoming highly competitive, largely no doubt in anticipation of further liberalisation at EC level. The Dutch and German post offices, amongst the largest in Europe, have in particular pursued active policies of acquiring courier; express delivery and parcel distribution services companies. The Dutch PTT has acquired TNT and Deutsche Post AG has made various acquisitions in the last two years. The UK Post Office has taken advantage of the relaxation of investment constraints on it by the UK government in late 1998 to acquire the parcel services company German Parcel Paket-Logistik $\mathrm{GmbH}$, reportedly Germany's fourth largest such company (announced in January 1999).

The challenge for the incumbent public postal services operators ('PPOs') will be to expand their activities outside their core geographical areas and core services so as to achieve an overall gain in business through the proposed liberalisation. This comes at a time when electronic communications are already eroding the core letter business of PPOs and putting pressure on their traditional revenues. The issues for the European Commission and the national regulatory authorities will be both to maintain the required levels of universal service and to 